\title{
CASE REPORT: RESECTION OF SYMPTOMATIC VOCAL CORD NODULE BY MICROLARYNGEAL SURGERY USING $0^{\circ}, 30^{\circ}$ ENDOSCOPE
}

Mahesh V. Kattimani ${ }^{1}$, Shweta Anand ${ }^{2}$

\section{HOW TO CITE THIS ARTICLE:}

Mahesh V. Kattimani, Shweta Anand. "Case Report: Resection of Symptomatic Vocal Cord Nodule by Microlaryngeal Surgery Using 0 $0^{0}, 30^{\circ}$ Endoscope". Journal of Evolution of Medical and Dental Sciences 2015; Vol. 4, Issue 66, August 17; Page: 11567-11569, DOI: 10.14260/jemds/2015/1669

ABSTRACT: Vocal cord nodules are benign reactive lesions commonly caused due to phonotrauma and vocal abuse. Patients with vocal nodules present with husky and breathy voice. These lesions are removed by microlaryngeal surgery using either operating microscope or endoscope. We present a case report of symptomatic vocal cord nodule which was precisely resected using $0^{0}$ and $30^{\circ}$ endoscope.

KEYWORDS: Vocal cord nodule, Microlaryngeal surgery.

INTRODUCTION: Vocal cord nodules are bilateral small swellings that develop on the free edge of the vocal cord usually at the mid-membranous portion. They are thought to be due to voice abuse ${ }^{1}$ rather than overuse ${ }^{2}$ and more commonly found in women under the age of $30.3,4$

The voice quality is often husky and breathy worsening with voice use. Patients with vocal nodules not responding to voice therapy are treated surgically ${ }^{5}$ with the aim of precise excision of the nodule alone and no exposure or damage to underlying ligament.6,7,8,9

In this paper, we report a case of symptomatic vocal cord nodule treated successfully by microlaryngeal surgery using $0^{0}$ and $30^{\circ}$ endoscope.

CASE REPORT: A 42 years old female ASHA worker presented with complaint of husky voice for the last 5 months. Her profession involved talking for prolonged periods in loud voice thus leading to voice abuse. Indirect laryngoscopy showed bilateral vocal nodules in the mid membranous portion. Right vocal nodule was reddish and considerably larger than the left one and solely impeding glottis approximation during phonation. These findings were confirmed by using $30^{\circ}$ endoscope in OPD and were documented. (Fig. 1, 2)

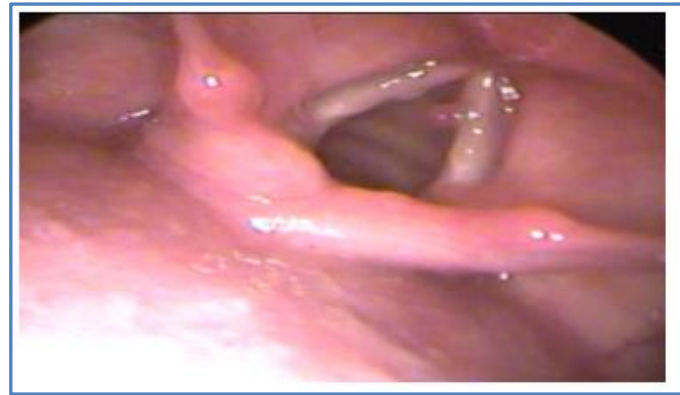

Fig. 1: Reddish nodule arising from rightt vocal cord

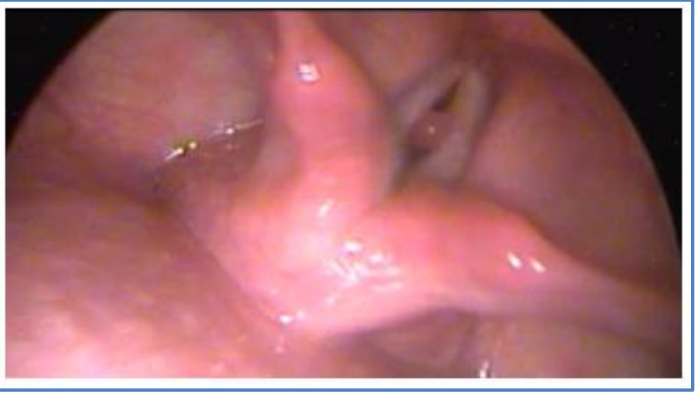

Fig. 2: Vocal cord nodule impeding glottic approximation

Voice therapy was advised for 1 month but still the patient remained symptomatic. Resection of right vocal nodule was done by microlaryngeal surgery using $0^{\circ}$ and $30^{\circ}$ endoscope under general 


\section{CASE REPORT}

anaesthesia. (Fig. 3) The centre of the right nodule was grasped by micro-cup forceps and pulled medially and micro-scissors were then used to cut the mucosa close to its base, thus preserving normal mucosa and keeping a straight vibratory edge. (Fig. 4).

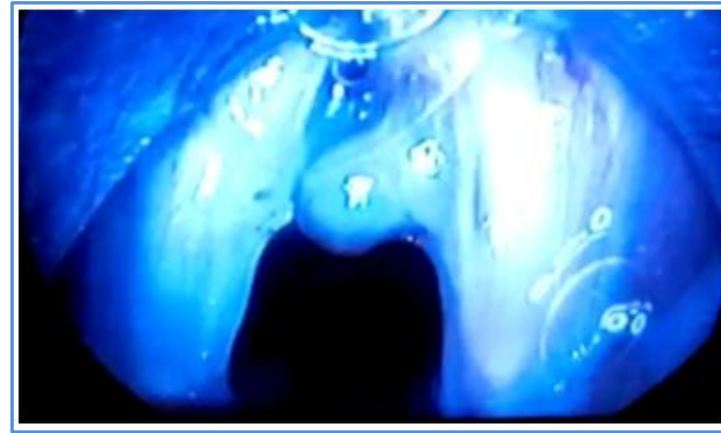

Fig. 3: Intraoperative endoscopic appearance of vocal cord nodule

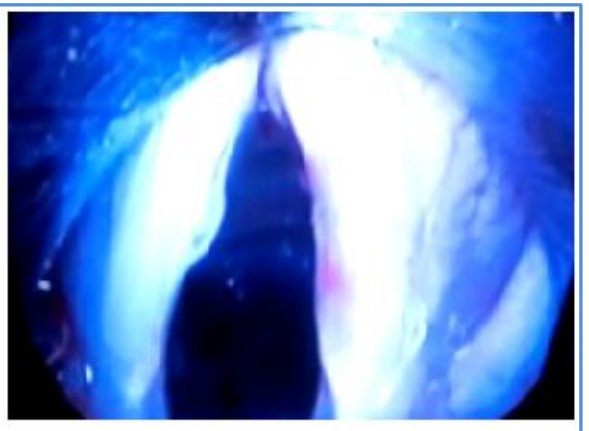

Fig. 4: Straight free edge of right vocal cord after resection of nodule

The histopathology showed squamous epithelial lining and subepithelial fibromuscular stroma with areas of hyalinisation suggestive of benign vocal cord nodule.

Postoperative voice rest for 48 hours was advised. Correct technique of voice production was also advised to prevent recurrence.

After 3 months of follow up no recurrence was seen. (Fig. 5)

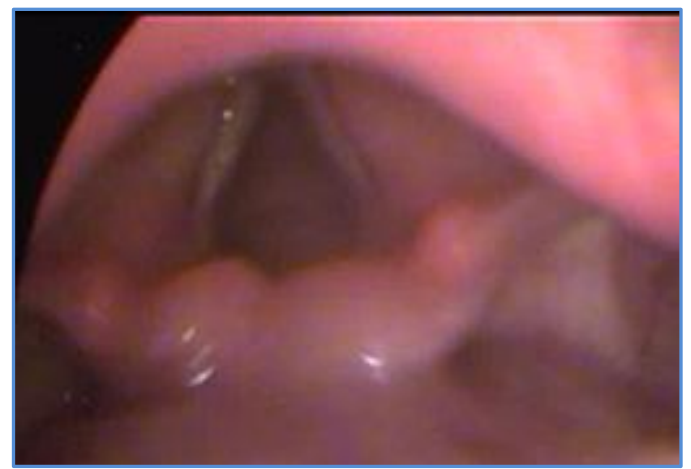

\section{Fig. 5: Endoscopic view of glottis} after 3 months of follow up

DISCUSSION: Vocal nodules are bilateral lesions of functional etiology. Damage of subepithelial blood vessels is the initial event in the evolution of vocal nodule. They start as soft reddish swellings. Gradually when the fibrous tissue proliferates, they become firmer and whitish in colour. Soft nodules are managed by speech therapy whilst hard nodules are managed by surgery and speech therapy.

Conventionally microlaryngeal surgeries are done using microscope, howewer endoscopic laryngeal surgeries have many advantages over microscope, field of vision and depth of surgical field are significantly greater than the microscopic approach. There is lesser need of refocusing to visualise the subglottic area and there is better visualisation of anterior commissure by using angled endoscopes. 


\section{REFERENCES:}

1. Yamaguchi H, Yotsukura Y, Hirose H. Non-surgical therapy for vocal nodules. Paper presented at the $20^{\text {th }}$ congress of the International Association of Logopedics and Phoniatrics. Logopedics and Phoniatrics, Issues for Future Research, Tokyo, 1986; 458-9.

2. Chalabreysse L, Perouse R, Cornut G, Bouchayer M, Loire R. Anatomie et anatomopathologie des leions benigned des cordes vocals. Revue Laryngologie Otologie Rhinologie. 1999; 120: 275-80.

3. Nagata K, Kurita S, Yasumoto S, Maeda T, Kawasaki H, Hirano M. Vocal fold polyps and nodules, a 10 year review of 1156 patients. Auris Nasus Larynx (Supplement). 1983; 10: S27-35.

4. Wendler J, Seidner W. Results of surgical treatment of vocal cord nodules and polyps in adults. Folia Phoniatrica. 1971; 23: 429-39.

5. Pederson M, McGlashan J. Surgical versus non-surgical interventions for vocal cord nodules. Cochrane Database Systemic Reviews. 2001; CD001934. DOI: 10.1002/14651858.

6. Zeitels SM, Hillman RE, Desloge R, Mauri M, Doyle PB. Phonomicrosurgery in singers and performing artists: Treatment outcomes, management theories, and future directions. Annals of Otolog, Rhinology, and Laryngology Supplement. 2002; 190: 21-40.

7. Bouchayer M, Cornut G. Phonosurgery for benign vocal fold lesions. Gibralter: The 3Ears Company Limited, 1994.

8. Bouchayer M, Cornut G. Microsurgical treatment of benign vocal fold lesions: indications, technique, results. Folia Phoniatrica.1992; 44: 155-84.

9. Bouchayer M, Cornut G. Instrumental microscopy of benign lesions of the vocal folds. In: Ford CN, Bless DM (eds). Phonosurgery. Assessment and surgical management of voice disorders. Raven Press, Ltd., 1997: 143-65.

\section{AUTHORS:}

1. Mahesh V. Kattimani

2. Shweta Anand

\section{PARTICULARS OF CONTRIBUTORS:}

1. Assistant Professor, Department of ENT, Basaveshwara Medical College Hospital \& Research Centre, Chitradurga.

2. Assistant Professor, Department of ENT, Basaveshwara Medical College Hospital \& Research Centre, Chitradurga.

NAME ADDRESS EMAIL ID OF THE

\section{CORRESPONDING AUTHOR:}

Dr. Mahesh V. Kattimani, \# 3/1024, Turuvannur Road, Near Reedy Kalyana Mantapa, Chitradurga-577501, Karnataka, India.

E-mail: magz0705@gmail.com

Date of Submission: 30/07/2015. Date of Peer Review: 31/07/2015. Date of Acceptance: 12/08/2015. Date of Publishing: 17/08/2015. 